\title{
MEDIA CONSTRUCTION OF MIGRANT CRISIS
}

\author{
Želimir KEŠETOVIĆ, PhD \\ Faculty of Security, University of Belgrade \\ Email: zelimir.kesetovic@gmail.com
}

\begin{abstract}
:
We are living today in the media constructed reality, so the media reporting is of utmost importance for public perceptions of different problems, issues and phenomena. This particularly refers to migrant crisis that European countries are increasingly facing the last few years. The media reporting on migrant crisis that emphasize threats to the national welfare system and culture might increase racism, xenophobia and islamophobia. On the other hand insisting on humanitarian themes might increase solidarity and tolerance. There are significant differences in media reporting on migrant crisis between media in European countries that are influenced by state policy, system of values, traditions, media systems and other factors. There is even no terminological consensus so different terms are used to address the phenomenon. Germany and Sweden, for example, overwhelmingly used the terms 'refugee' or 'asylum seeker', whilst Italy and the United Kingdom press preferred the word 'migrant'. In Spain, the dominant term was 'immigrant'. These terms had an important impact on the tenor of each country's debate. In this review paper a comparative overview on media reporting on migrant crisis in five EU countries, Croatia and Serbia will be given, based on conducted researches, followed by the attempt to explain the differences and construct the models of media reporting on migrant crisis. Media reports and texts often burdened by ignorance, stereotypes and prejudices should be replaced by analytic texts based on ethic norms and standards of journalist profession and basic human values.
\end{abstract}

Key words: media, migrant crisis, perception, agenda setting, Serbia

\section{Introduction}

The beginning of the actual migrant and/or refugee crisis can be traced back to 2011, when a large number of people from Libya arrived on the coast of Sicily, while a smaller number arrived from Turkey to Greece. The crisis unfolded with the "Arab spring", when the real refugees from the wider Middle East (Syria, Iraq, Yemen), North and Central Africa (Libya, Eritrea, Somalia, 
Sudan, Nigeria) and central and southern Asia (Afghanistan, Pakistan, Bangladesh) headed towards Europe in eight directions, one of the more strategically important ones going through the Balkans ("Balkan route"). The "democratic states" were stating that they did not notice a growing problem, although in 2013, the number of refugees in the world reached 214 million, the next year it reached 244 million, and at the end of 2015 it exceeded a quarter billion. Figures from the UNHCR (2015) revealed that in the first six months of 2015137,000 refugees and migrants attempted to enter the EU, a rise of $83 \%$ on the same period in 2014 . This increase is largely attributable to the sharp rise in people using the Eastern Mediterranean route from Turkey to Greece, the great bulk of whom are refugees fleeing the wars in Syria and Iraq. Since the beginning of the Syrian civil war, the number of refugees in Turkey has risen to more than 2 million. (Berry, Garcia-Blanco and Moore, 2015) This crisis has also affected Serbia since it is on the Balkan route. Looking for the road to Western Europe in 2015, about 1000 migrants entered the country daily. The complexity of the situation caused by the tendency of Hungary to limit their uncontrolled influx led to the closure of the Hungarian-Serbian border, along which barbed wire was placed. Such a procedure has caused negative reactions both in the Serbian public and among European officials. Moving migration flows to Croatia has caused similar problems. The European Union has reached an agreement with Turkey and managed to stop migratory waves towards Europe, but it is not certain for which period.

The causes that led to the explosion of the migrant crisis in 2015 are diametrically different: the escape from war, the search for a better life, the departure from dysfunctional states, and the escape from various forms of extremism and terrorism. Besides a number of factors such as increase in the numbers and visibility of migrants in recent years, economic factors as Global Financial Crisis in 2008 followed by social insecurity, concerns over national security and cultural assimilation, the rising popularity the far right etc., an important role in influencing public and elite political attitudes towards asylum and migration belongs to mass media. They are "gate keepers" and "agenda setters" who are framing the debate. They define our world and main problems, including the problem of migrants, by providing the information which citizens use to make sense of the world and their place within it. (Berry, Carcia-Blanco and Moore, 2015). In this paper we will present a brief overview of the media reporting in European media, and a more detailed presentation of media coverage of this topic in Serbia.

\section{Migrant crisis in European media}

The arrival of a large number of refugees and migrants to Europe has posed a great challenge to the media and journalists. Media must pay particular attention when reporting about vulnerable groups, among which are refugees and migrants. When the refugee wave shook Europe, it was necessary to decide for the media how to report on this problem. Worldwide experiences of journalist reporting on migrants vary greatly from country to country, but they have several common points of modeling. The most common trap in which the media can fall relates to 
unethical and sensational reporting, hate speech, the oversimplification in which a certain group is stigmatized, incomplete or fictional stories, but also serving to the political propaganda of the ruling elites (Jevtović and Bajić, 2017)

Media across Europe and the world were tracking this crisis, making detailed reports and reportages, but what could be seen in the writing of the media is their bias, oscillations in reporting, such as, for example, the ideological closeness to a certain political party, the display of only one viewpoint of the refugee crisis, giving no media space to refugees and the changing attitudes towards refugees during the development of the crisis (Pelizzoti, 2016).

In the most of media, refugees are presented as a threat. Such portraiture of refugees mostly goes hand in hand with politicians who try to depict refugees as people who are seizing jobs, becoming social cases and living at the burden of the state, and who do not want to adapt to the culture and the way of life of the host country. (Moving Stories, 2015:7)

The Cardiff School of Journalism under the commission of UNHCR explored the drivers of the media coverage of migrant crisis in five different European countries: Spain, Italy, Germany, the UK and Sweden. Researchers combed through thousands of articles written in 2014 and early 2015, revealing a number of important findings for future media advocacy campaigns. Most importantly, they found major differences between countries, in terms of the sources journalists used (domestic politicians, foreign politicians, citizens, or NGOs), the language they employed, the reasons they gave for the rise in refugee flows, and the solutions they suggested. Germany and Sweden, for example, overwhelmingly used the terms 'refugee' or 'asylum seeker', while Italy and the UK press preferred the word 'migrant'. In Spain, the dominant term was 'immigrant'. These terms had an important impact on the tenor of each country's debate. Media also differed widely in terms of the predominant themes to their coverage. For instance, humanitarian themes were more common in Italian coverage than in British, German or Spanish press. Threat themes (such as to the welfare system, or cultural threats) were the most prevalent in Italy, Spain and Britain. Overall, the Swedish press was the most positive towards refugees and migrants, while coverage in the United Kingdom was the most negative, and the most polarized. Amongst those countries surveyed, Britain's right-wing media was uniquely aggressive in its campaigns against refugees and migrants.

\footnotetext{
${ }^{5}$ However, it would be wrong to give general assessments of media coverage of the refugee crisis as there are significant differences between individual countries, as well as between the media within a particular country. Representations of refugees in media and political discourse in relation to Germany participate in a Gramscian "war of position" over symbols, policies, and, ultimately, social and material resources, with potentially fatal consequences. These representations shift blame from historical, political-economic structures to the displaced people themselves. They demarcate the "deserving" refugee from the "undeserving" migrant and play into fear of cultural, religious, and ethnic difference in the midst of increasing anxiety and precarity for many in Europe. Comparative perspectives suggest that anthropology can play an important role in analyzing these phenomena, highlighting sites of contestation, imagining alternatives, and working toward them (Holmes and Castaneda, 2016).

${ }^{6} \mathrm{It}$ is not just about terms. Behind of each of this term there is a very different legal and social position of these people and the systemic measures that the state can and should take, the problems and obligations that politicians, through whose countries they pass and stay in, have to solve.
} 
The key conclusions of this research are:

1. There are wide variations in how the press in different countries report on asylum and immigration - Sweden was the country whose press system was the most positive towards refugees and migrants while in contrast, coverage in the United Kingdom was the most negative.

2. There are significant differences in the level of variation within national press systems - in Spain, Italy and Sweden the press, regardless of political orientation, reported on asylum and immigration in broadly similar ways (using the same language, report on the same themes and feature the same explanations and responses), whilst in other countries reporting was highly varied.

3. The European Union's response to the crisis was widely seen as inadequate, yet it was still defined as the key institution responsible for solving the crisis - Newspapers in continental Europe agreed that the crisis should be solved collectively, at the EU level, rather than by individual member states. In Italy it was seen as unwilling to share the burden for search and rescue operations, and the reception of refugees and migrants. In Germany and Sweden, there was extensive criticism over the unwillingness of EU states to share the burden of refugee settlement

4. The degree to which asylum and immigration is subject to political contestation is a key factor structuring coverage - there are few parties with explicit pro-refugee and promigrant policies. In Sweden, Italy and the UK the challenge to government policy has come from the far-right, and in Germany, besides far-right party also from the left parties and Greens. In Spain the issue is not a significant campaigning issue.

5. The rise of the far-right has been reflected in uneven media coverage - In Cermany the rise of the far-right has not been reflected in any significant media access, while in Italy the far-right has a prominent voice because of its electoral legitimacy, and in Sweden, the recent electoral success of the Swedish Democrats has opened up their access to the media. In Britain, the rise of UKIP has been reflected in significant source access to all newspapers.

6. There was a substantial shift from the first sample to the second in relation to how the conflict was explained and what solutions were visible - whilst the first sample primarily viewed the crisis as stemming from migration flows driven by wars, human rights abuses and repressive regimes, the second sample - particularly in the UK, Italy and Spain focused much more on the chaos in Libya and the role of people smugglers.

7. Overall there were few instances where reporting focused on the benefits that asylum seekers and migrants could bring to host countries - only in in the Swedish and German press.

8. The local context is vital in shaping how news is reported - particular national journalistic conventions and political traditions determine the appropriate labels or angles that are taken on stories 


\section{There were very few articles which focused on the need to address the push factors driving population flows (Berry, Garcia-Blanco and Moore, 2015)}

\section{The migrant crisis in Serbian daily press}

Journalists from Serbia and former Yugoslav countries have also found themselves in front of dilemmas how to report on migrant crisis. Journalist associations from the region gathered in the regional project MEDIA CIRCLE (including the Partnership for Social Development from Croatia, the journalists association Vesta from Bosnia and Herzegovina, Yucom - Lawyers Committee for Human Rights and the Independent Society of Journalists of Vojvodina from Serbia, Institute for Public Policy from Montenegro and the Center for Research, Communication and Development Public from Macedonia) and appealed to all those who are referring to the refugee crisis in the public space or report to the media to adhere to certain rules. These associations invite the media to avoid politicization, stereotyping, collective hysteria (whether positive or negative) and avoiding any politicization of the refugee issue in the countries of transit and countries of destination. Furthermore, they warned that it is wrong to use any ethnic or religious epithets, such as the Arabs, Muslims, Asians, Afghans and the like, along with the name of the refugees. They recommend referring to refugees from a certain region in the public media, because it is unprofessional, inaccurate, wrong and contrary to the law to qualify them according to a unique ethnicity or belief. They point out that in mass refugee migrations, no stereotyping of the "behavior and culture" of refugees is desirable in public speech, as any such treatment harms refugees in the countries in which they find themselves. They agree that every refugee story in the public space should be addressed individually, by name and surname, taking into account the diversity of each family and the person being reported. In addition, they point out that only in this way will the large majority of refugees be protected from violence, insults, discrimination and everything that follows them on their way and socialization in host societies after their journey ends. They recommend also avoiding the stereotyping of persons, especially officials in transit countries and countries of destination, who interact with refugees. They consider that every good deed has its own name and surname, and that it is important to individualize good deeds in public speech, because only by such approach can the great majority of people be motivated to do the same. The associations also called for respect for the privacy of refugees and for photographing them only if they permit it. It should be kept in mind that these photographs should protect their identities. They point out that by photographing the face of refugees they can endanger their lives or the lives of their loved ones, who were not lucky to avoid a war disaster. In reports on figures, statistics or other indicators accompanying the refugee wave, it is called upon to use only the official reports that were previously verified by the competent national authorities and international organizations. Finally, the associations remind that professional and ethical standards of journalism oblige all journalists and editors to objectively, comprehensively, equitably and in human way report on refugees without hate speech, discrimination or calling for violence (Hnd.hr, 2015) 


\section{Securrity}

It can be noted that most of these recommendations have not been fully respected, especially when it comes to tabloids. In the following chapters we will summarize the results of relevant researches of the presentation of migrant crisis in Serbian daily press.

\section{The migrant crisis in Serbian daily press - quantitative aspect}

There are three important research report on presentation of migrant crisis in Serbian daily newspaper: Aracki, 2016; Jeftić and Bajić, 2016; and Jeftić and Bajić, 2017. Jeftić and Bajić used quantitative and qualitative content analysis in researching typical narratives and forms that were used in representation of the migrant crisis, primarily related to the Balkan route, on the cover pages of Serbian daily newspapers (Politika, Danas, Večernje novosti, Blic, Kurir, Alo and Informer) in 2015.

The migration crisis was in focus of the Serbian press in 2015, when almost 16 percent of the total number of front-page pages were dedicated to this topic, whilst in 2016 the daily newspapers' interest almost halved (around $8 \%$ ), with the tendency of the further marginalization of the whole problem (in the first quarter of 2017, slightly more than 4\%). This in no way reflects the situation on the ground since the migration crisis has not been resolved and the Balkan route has not been completely closed. 7 A significant drop in attention after 2015, despite the ongoing the migration crisis, means that in practice there has been a silent change in the paradigm. (Jevtović and Bajić, 2017)

Refugees, asylum and migrations since 2015 have become permanent narratives in the press of Serbia, with several themes-dimensions:

- humanism (Serbia is visibly different in comparison with others, especially Croatia and Hungary);

- solidarity and mobilization of citizens to help migrants;

- cosmopolitanism (ideological, political and religious);

- multiculturalism and

- networked collectivism.

However, with the flow of time, the tone was gradually changing, so that the negative attitudes became more salient and frequent, which is especially expressed in tabloids, in order to move into the last phase in positive tone and the need for their longer stay in Serbia. From the beginning of 2016, the emphasis has been put on the voices that spoke to Serbia as the last refugee station, which is a fundamental change in the paradigm. A quiet modeling of the mass begins, but in order to prepare the domestic public, the ideas about the possible retention of migrants were being slowly launched (Jevtović and Bajić, 2017).

\footnotetext{
${ }^{7}$ Discourse in the public space normally does not represent a mapping of reality, but rather an ideological interpretation of real events and processes, aligned with the ideas and orientations of the ruling establishment. (Jevtović and Bajić, 2017)
} 
The research indicates prevailing communicative Manichaeism characterized, on the one hand, with prevalence of sensationalist and xenophobic discourses based on the fear of newcomers; on the other hand, discourses emphasizing the humanity, mostly in treatment of migrants in Serbia, as well as through their individual life stories. ${ }^{8}$ As the main results, the research points at the absence of wider role of investigative journalism, deeper analysis of the current problems that Serbia is facing, combined with the fact that sources of dominant attitudes usually come from the ruling political elite. Practice shows that superficial, formatted, sensationalist and spun presentation of migrant crisis in the Serbian daily newspapers provide the soil for spreading the stereotypes about the place of migrants in society, thus making significant obstacles to their integration into the concept of slowly emerging civic community. (Jeftić and Bajić, 2016).

Graph 1. Intensity of reporting on the European migrant crisis (number of headlines) by quarters in the period January 2015 - March 2017

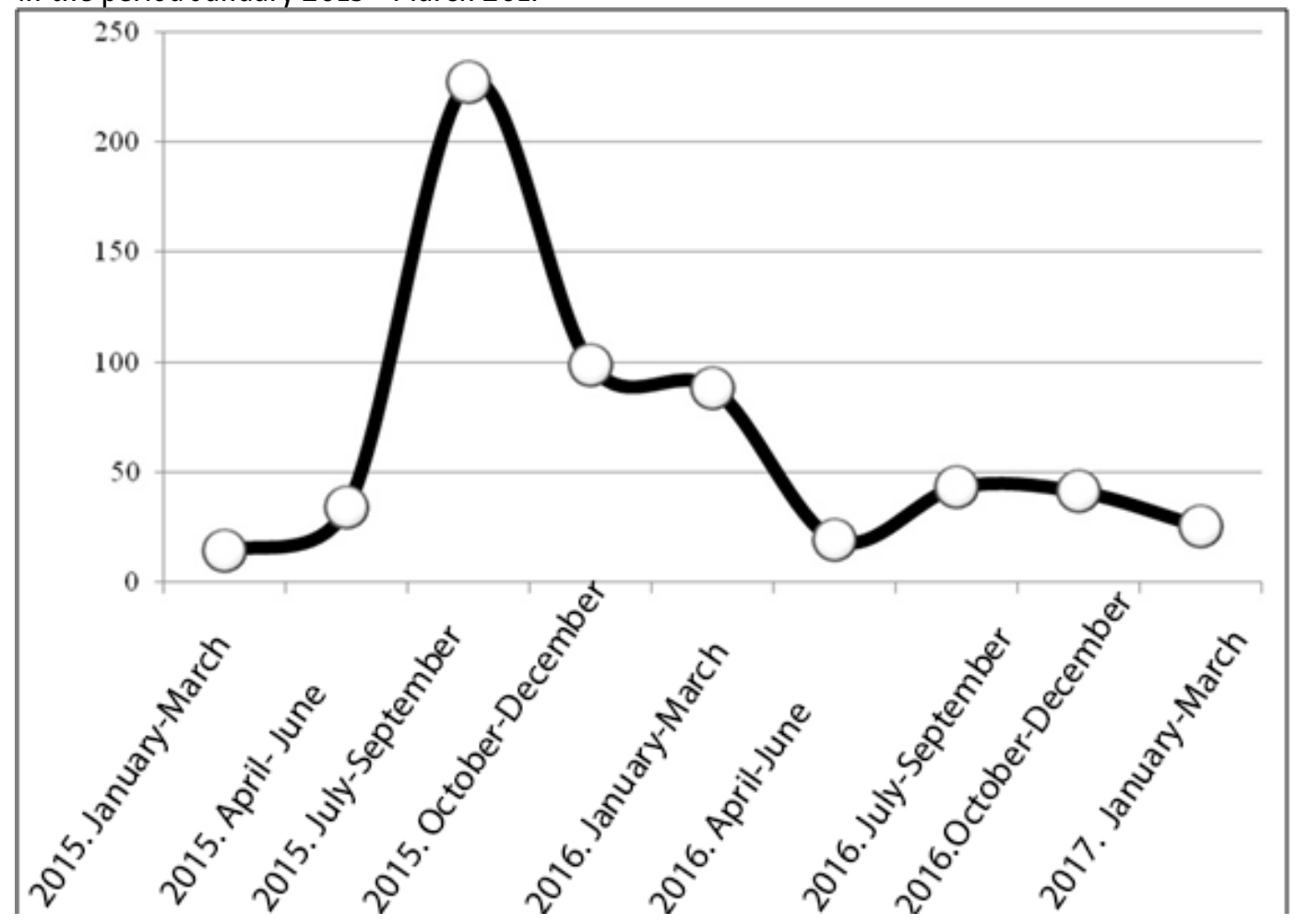

Source: Jevtović and Bajić, 2017

8 Tabloids persistently appealed to sensationalism, xenophobia and fear of Islamic radicalism, whilst quality daily newspapers promoted the human aspect of the Migrant crisis. 


\subsection{The migrant crisis in Serbian daily print - qualitative aspect}

At the beginning of the refugee crisis, it was easy to recognize the compassion, curiosity and fear in the media content, because the citizens of Serbia, through their own tormented experience, developed empathy towards the people in trouble who arrived on a daily basis. ${ }^{9}$ The serious newspapers determined the dominant tone, following the strategic position of the state authorities, which increased the visibility of the migrant crisis by organizing pseudo-events, press releases, press conferences or giving statements during field visits. Most of the articles have been published in Politika, followed by Danas (Jevtović and Bajić, 2017)

Similar to the worldwide reporting, in the Serbian media there was no terminology agreement on how to call people with small children in arms, bundles of clothes, with some sum of euros or dollars in their pockets: whether they are migrants, asylum seekers, irregular migrants, refugees, immigrants, illegal migrants, emigrants, illegal migrants. In the practice of the Serbian media, the most commonly used term was somewhat impersonal and neutral - migrants. Almost twice less was used the word refugee. (Aracki, 2016)

In reporting on migrant crisis two dominant discourses in Serbian daily press can be observed:

- Xenophobic - centered on a conspiracy theory about the planned migration of Islamic population to the European soil, thereby destroying European cultural identity, with an increased danger of terrorism, and

- Discourse of humanitarian disaster, human solidarity and respect for human rights (Aracki, 2016)

The socio-security paradigm of migrants (migrants as a security threat) and the changes they bring into the everyday environment is based on media narratives as sets of phenomena and events that as a goal have an overview of a particular topic in which more or less we want to believe. In doing so, creating title blocks, choosing facts and arguments, interpreting angles, publishing intensity, and similar attention-generating techniques depend on editorial teams that pack reality into media truth used as a propaganda tool. Hence, the media content is not usually a mapping (reflecting) of reality, but an ideological interpretation of real events, adapted to the demands of the ruling establishment. By a superficial analysis of the Serbian press, we can observe a wide range of circumstances and topics in which the migration crisis, migrants, asylum seekers and refugees are mentioned on the front pages. The attention of readers is drawn to the policy of the European Union and the views of politicians and citizens; the crisis in the region (special themes are the new built wall on Hungarian borders, Croatian blockade, and events on the borders of Macedonia, Bulgaria and Greece), the views of the UNHCR and the Red Cross, and appropriate service information (road passage, lack of food and water). Among the readings are the life stories and tragedies of migrants, "expert" analyzes (whether there are "sleepers" among them?),

\footnotetext{
${ }_{9}^{9}$ Similar narratives could be observed in the media in Croatia (Mešanović, 2017; Pelizzoti, 2016)
} 
trafficking in migrants, criminal acts like smuggling and issuing false documents, blocking borders or connecting with the fate of refugees from the former SFRY. (Jeftić and Bajić, 2016).

Ever since 2015, the European Union policy and the views of local politicians and citizens towards this policy have been in focus, while in 2016, in the public space migrants were also used as "bartering goods" in international relations, primarily between the European Union and Turkey. The focus of the critic was on the European Union, in particular Croatia and Hungary, as the first Serbian neighbors and EU frontiers gatekeepers and their attitude towards migrants. For example, Politika on April $7^{\text {th }}$ writes: "Bugari žicom brane Evropu od izbeglica" - "Bulgarians defend Europe from refugees with a wire", and two weeks later this daily paper is even sharper: "Mediteran guta imigrante i savest Evrope"-"The Mediterranean is swallowing immigrants and the conscience of Europe". When Blic on Avgust 22 ${ }^{\text {nd }}$ writes: "The wave of migrants turns into a humanitarian crisis - Others beat them", it aims at the incredible ability of the press to rapidly arouse a mass audience. Warm and human stories about unusual fates and personalities, complications and happy outcomes are the easiest way to attract the audience. Attention is rapidly conquered when the press turns to the heart, and not to the intellect, combining the text with the photo and using emotional language. A dashing photo of a Serbian policeman holding the Syrian boy in his arms touched the whole world, sending a message about a different and better Serbia. Tabloids first spotted this event, and Alo on September 10 and 11 under the title "This is Serbia!" publishes the image of policeman Rexhep Arif who says "I would cuddle my own son this way if I had son." Emotional agitation is the favorite technique of any propagandist, so it is not surprising that other newspapers give significant space to this topic, some of whom use this event to teach the lesson to others. For example, Blic, on September 11th, is noting that "the whole world praises Serbia" in the first plan highlights "Touching images of the state and citizen's attitude towards the refugees" that "break down the negative prejudices about us created since the 1990s", but at the same time publishes a photo with a signature: "Shame: Hungarians welcome migrants with masks". In the shadow of the big stories with much less attention, the photo was made by a BBC journalist (Politika, September 11) (Jeftić and Bajić, 2016).

We see a new phenomenon: a transferred worldview - the hidden intent of a newsmaker and informative content based on the unnecessary production of stereotypes and prejudices that are rooted deep into the mental tissue of the auditorium. In that sense, the tabloids are ahead. Informer on 16 September thoroughly claims that it is on the pier: Humanitarian catastrophe that "Serbia is the victim of EU fascism", whereby "Hungarians return migrants, Croats threat with minefield»! A newspaper close to the official policy of the government argues that "Brussels silently supports a policy that will turn out Serbia into a refugee camp for hundreds of thousands of refugees from the Middle East" which aroused fears among its readers. The day after the briefing continued with the headline titles: "The end of the great migrant crisis cannot be seen - Shame on Europe" with the information that "Hungarians captured even the five days old baby "whereas "Croats arrest all migrants", further complicating the heated atmosphere. On the other hand, the media were constructing a paradigm according to which Serbia has been the only 


\section{Securitity}

country in the SEE that has a consistently human relationship and approach towards refugees. (Jeftić and Bajić, 2016).

Conspiracy theories are used to increase the circulation. Therefore Kurir on August 24 with a large headline block raised the auditorium temperature: "The Hell of a Plan - Greece and Macedonia: Forward all migrants to Serbia!" The rhetoric of tabloid media in a specific way hyperbolizes the overall situation, and terms such as "drama", "breakthrough", "threat", "invasion", "disaster", "chaos" and alike raise tensions and atmosphere of conflict, although in reality the situation is under control. Reports and headlines announce the disasters, characterized by strong words, sensationalism, mentioning the suspicious persons labeled as terrorist crossing the border, which exacerbates mistrust towards migrants. Thus, Informer on June 22 writes about the "Invasion of Migrants", Blic warned on August 11: "All Syria will blow through Serbia, whilst the Kurir announces on August 26th: „The Bloody Scenario in Serbia - The Right wing extremists are preparing to lynch the migrants". (Jeftić and Bajić, 2016).

Daily Newspaper Danas introduces a religious factor in the public space and the titles "Christian Viktor Orban again "defends Europe" (September 4th) or "Orban sent "crusaders" to the border"(September 5) encourage other media to point the religious issue to the forefront. On the front page of the Politika on September 9 appeared the text "Christian welcome, there is no place for Muslims", noting that "clergy do not listen to the superiors, nor read the Bible, but defend Europe from Islam." The threat of a new crusade is part of a massive panic that intimidates the audience, so it is not surprising that the title: "Will the Islamic State turn Europe against Refugees" (November 16th) to conclude that "Islamists will welcome a conflict between Christians and Muslims in Europe" (Jeftić and Bajić, 2016).

In addition to reporting on the refugee crisis for the analysis of media discourse, the category of absence is also very important. It refers to the issues that were not in the media or were only sporadically represented. For example, during the period when migrants were the most talked about, the negotiations were taking place in Brussels between Belgrade and Pristina, and four agreements were signed with the representatives of the self-proclaimed state of Kosovo, the issue of new elections was launched, while in the public leaked the recording of the meetings of the current Foreign Minister and a compromised person with a criminal record. Thus, in a certain sense, the refugee crisis was used to divert public attention from other important socio-political topics and events, in accordance with the interests of the ruling actors. (Jeftic and Bajic, 2016).

It can be noted that reporting on migrants in the Serbian daily press was mainly balanced, but also that it was in the function of the political marketing of the ruling establishment. The instrumentalization of media content is difficult to see, because the news are cunningly turning to the benefit of one side (usually those in power), and by overstating the importance of events, appearances or persons, the media create dominant value patterns. ${ }^{10}$ There has been a lack of

\footnotetext{
${ }^{10}$ It should be mentioned the narrative about Serbia as a victim of a non-unified European policy in the function of the cohesion of the domestic population, which should not be overly concerned because it has its own political leadership that is firmly in control of the situation.
} 


\section{Security}

discussion in the public sphere, so that the change of citizens' awareness takes place inadmissibly slowly and depending on the opinions of the ruling structures. (Jevtović and Bajić, 2017)

\section{Citzens attitudes towards migrant crisis}

Recent researches have shown that Serbian citizens have a neutral attitude towards migrants but with the intensification of the refugee crisis, the number of the indifferent ones decreased, and the differentiation towards those with predominantly positive and negative attitude became stronger.

Graph 2: Comparative review of the UNDP Survey from 2016 (Galup) and UNHCR from 2014 (Cesid)

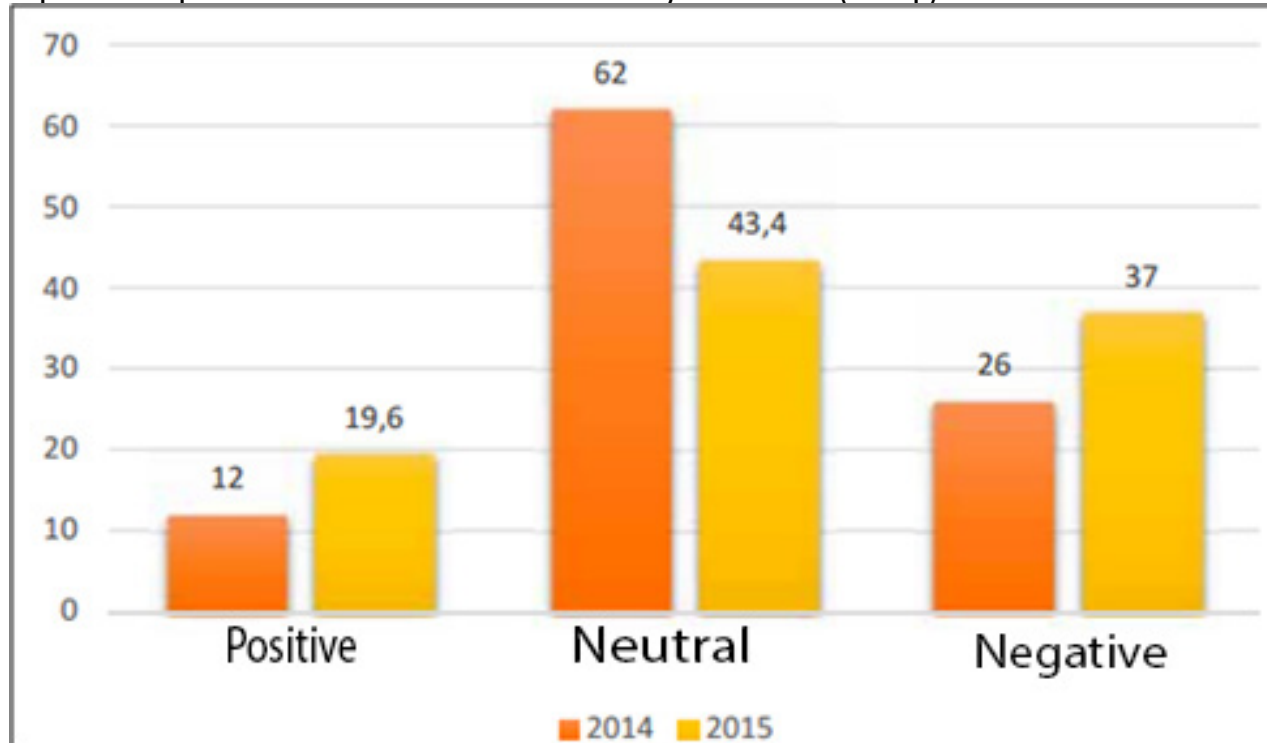

Source: Vuletić et al., 2016:7

In Serbian public the humanitarian approach dominates. Three quarters of the population (75\%) shows strong or very strong humanitarian attitude towards migrants, while on the other hand slightly more than half $(52.9 \%)$ of respondents have a very or very strong security attitude towards migrants. Citizens of Serbia have largely formed their attitudes towards migrants and their views on migrant crisis under the influence of the mass media and the ways in which they reported on this phenomenon (54.1\%). 


\section{Securiaty}

Graph 3: Sources that influence attitudes towards migrant crisis

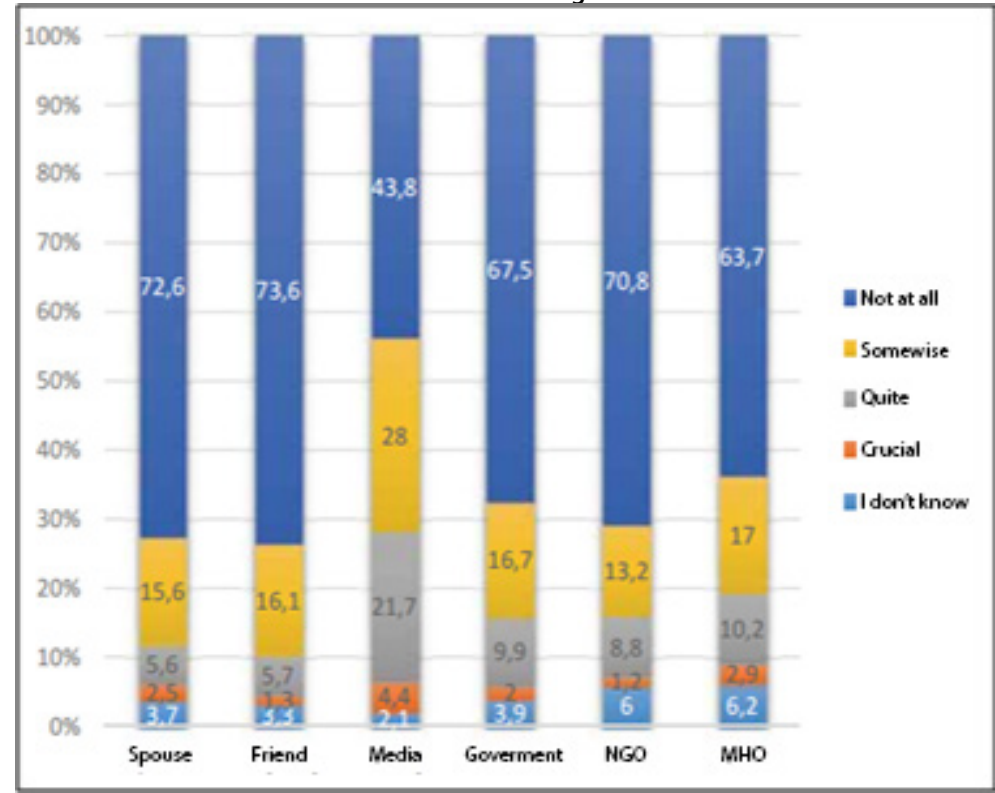

Source: Vuletić et al., 2016: 13

\section{Conclusion}

At its peak in 2015 the migrant crisis has become one of the most important stories in the printed and electronic media both worldwide and in Serbia. The media, in synergy with the holders of political and economic power, defined and framed this phenomenon and influenced the way in which it was perceived by the public. Media narratives varied, depending on the interests and positions of individual states and their media, as well as the values and ideological orientation of individual media. The dichotomy between the tabloid and serious press is very present, and the bulk of it uses a sensationalist and xenophobic discourse based on the fear of the newcomers and theses about the planned islamization of Europe, whereas the counter-narrative forces the humanitarian dimension of disaster, concern for the others and respect for human rights.

The mismatch of views on the migrant issue, including the varying terminology, the sensationalistic reporting and the lack of analytical approach, caused considerable confusion over the whole issue of the migrant crisis.

Particular topics raised more attention in some countries, and their attitudes towards this crisis and the way in which it has been dealt with, as well as the degree of criticism towards the EU policy on this issue, were conditioned by the position of each country, depending on whether it is a country that is the first acceptance of migrants (like Italy) or the country of their final destination (like Sweden and Germany). Reporting methods and sudden shifts of tones and 
discourses were also affected by certain events that received great media attention, such as the image of the drowned Syrian boy Alan Kurdi on the Turkish coast who woke up pity and directed the discourse in the direction of humanitarian issue, to terrorist attacks directing the media approach to Islamophobia and security threat.

In the Serbian media there has also been a terminological confusion regarding migrants as well as a dichotomy of humanitarian and xenophobic discourse. Also, the tone and the framing of individual problems changes with the change of the manifestation of the humanitarian crisis. At the very beginning, Serbia was exclusively a transit country, and during the time when neighboring countries closed the borders, Serbia became a country in which migrants stayed longer, due to which the topics and approaches in the media changed accordingly. Media are insisting on the human image of Serbia, its citizens and its authorities in contrast with the behavior of certain neighboring countries, and fears of the future development of this crisis and the potential position in which Serbia could be found.

It is necessary for the media and journalists to abide by ethical norms and professional standards in reporting on refugees and not to be subject to the hysteria of xenophobia and Islamophobia, but, on the other hand, not to neglect the potential security problems of the migrant crisis and to report about them in a professional and responsible manner, avoiding sensationalism. The same goes for the humanitarian aspects of this crisis in which the media must have the necessary dose of empathy, but at the same time they should avoid the position of the "crying mother" and not use the human troubles in a sensational way to increase the circulation.

Analyzing geopolitical processes, climate change, energy conflicts and military-security conflicts, it is possible to foresee more permanent retention and integration of migrants in European territories, which in long-term plans include Serbia, although this is not discussed in Serbian public. (Jevtović and Bajić, 2017) In a certain way, the European Union is in front of the crossroads, because it is necessary to quickly align several different multi-dimensional platforms on migration: such as a coherent migration policy acceptable to all MS; absorption of opportunities for acceptance of migrants and sustainability of social cohesion within European countries; the concept of multiculturalism; respect and protection of human rights, etc. A particular challenge is the integration of migrants and their acceptance of the values that exist in the environments in which they come. In this case, the media may have a special role, since they must be open to both the domestic population and the newcomers (Aracki, 2016).

\section{REFERENCES}

1. Aracki, Z. (2016),"Medijski diskurs izbeglištva", Kultura polisa, Vol XIII No 31 str. 45-55.

2. Berry, M., Garcia-Blanco, I. and Moore, K. (2015) "Press Coverage of the Refugee and Migrant Crisis in the EU: A Content Analysis of Five European Countries", Report prepared for the UNHCR (December 2015), Cardiff School of Journalism, Media and Cultural Studies, available on http://www.unhcr.org/56bb369c9.html, 10/01/2018. 


\section{Security}

3. Heribert Schatz Christina Holtz-Bacha Jörg-Uwe Nieland (Hrsg.) (2000) Migranten und Medien - Neue Herausforderungen an die Integrationsfunktion von Presse und Rundfunk, Springer Fachmedien Wiesbaden $\mathrm{CmbH}$

4. Hnd.hr (2015) „Ne činite štetu, molimo vas! Javni poziv novinarima/kama, urednicima/cama i svima drugima koji izvještavaju ili javno govore o izbjeglicama danas", 21.09.2015.,http:// www.hnd.hr/ne-cinite-stetu-molimo-vas-javni-poziv-novinarima-kama-urednicimacama-i-svima-drugima-koji-izvjestavaju-ili-javno-govore-0-izbjeglicama-danas (01.04.2017.)

5. Holmes, S.M., and Castaneda, H. (2016), "Representing the "European refugee crisis" in Germany and beyond: Deservingness and difference", life and death, American ethnologist, Vol. 43, No. 1, pp. 12-24.

6. Hrnjić Kuduzović, Z. (2017) "Uloga elitnih izvora u izvještavanju o migrantskoj krizi u dnevnim novinama Oslobođenje, Jutarnji list i Politika," in Car, V. i Matović, M (ur.), Zbornik radova 7. Regionalne znanstvene konferencije Vjerodostojnost medija "Novinarstvo i ljudska prava", pp. $57-74$.

7. Jeftić, Z., Bajić, P. (2016), “Migrantska kriza u ogledalu srpske dnevne štampe, Kultura polisa, Vol XIII, No 31 str. 29-43

8. Jevtović,Z.i. Bajić, P. (2017)„Promena komunikacioneparadigmeu izveštavanjuo migrantima u dnevnoj štampi Srbije“, in Despotović, L. i Gajić, A. Kultura bezbednosti:migrantske krize, stanje, perspektive, rizici, Kultura polisa - posebno izdanje, Vol, XIV, pp. 221-239.

9. Jurišić, J., Vesnić Aujević, L. i Bonacci, D. (2017) "Stvaranje agendi: slučaj izbjegličke krize u hrvatskim medijima" in Car, V. i Matović, M (ur.), Zbornik radova 7. Regionalne znanstvene konferencije Vjerodostojnost medija „Novinarstvo i ljudska prava“" pp. 39-56.

10. Mešanović, E. (2017) Portretiranje izbjeglica i migranata u središnjim informativnimemisijama HRT-a, RTL-a iNove TV - diplomski rad, Zagreb: Fakultet političkih znanosti.

11. Moving Stories: International Review of how Media Cover Migration (2015), London: Ethical Journalism Network.

12. Pelizzotti, N. (2016) Analiza medijske slike o migracijama u Europu 2015. i 2016, diplomski rad, Zagreb:Sveučilište u Zagrebu-Hrvatski studij

13. Vuletić, V., Stanojević, D., Vukelić, J. and Pešić, J. (2016), Studija o izbeglicama-Srbija 2016, Beograd: Friedrich Ebert Stiftung 